\title{
Pengaruh Motivasi Kerja dan Kompensasi Kerja Terhadap Produktivitas Kerja Karyawan
}

\author{
Pertiwi Agustina $^{1}$, Gatot Kusjono ${ }^{2 *}$, Suprianto ${ }^{3}$ \\ ${ }^{1}$ Mahasiswa Manajemen (NIM. 2016053798), Universitas Pamulang; pertiwiagustina04@gmail.com \\ ${ }^{2,3}$ Fakultas Ekonomi, Universitas Pamulang; dosen00434@unpam.ac.id*
}

Received 09 Februari 2021| Revised 09 Maret 2021 | Accepted 25 Maret 2021

*Korespondensi Penulis

\begin{abstract}
Abstrak
Penelitian ini bertujuan untuk mengetahui pengaruh motivasi kerja dan kompensasi kerja terhadap poduktivitas kerja karyawan. Metode yang digunakan dalam penelitian ini adalah metode kuantitatif dan data dikumpulkan menggunakan kuesioner. Jumlah populasi dan sampel sebanyak 67 responden. Analisis yang digunakan meliputi: uji validitas, uji reliabilitas, uji normalitas, uji multikolinearitas, uji heteroskedastisitas, regresi sederhana, regresi berganda, analisa koefisien, uji t dan Uji F. Hasil uji parsial diperoleh motivasi kerja dan kompensasi kerja berpengaruh positif dan signifikan terhadap produktivitas kerja karyawan. Sedangkan hasil uji simultan motivasi kerja dan kompensasi kerja berpengaruh positif dan signifikan terhadap porduktivitas kerja kayawan dengan nilai Fhitung 69,437 > Ftabel dan probability signifikansi 0,000 dengan konstribusi sebesar 36,9\%
\end{abstract}

Kata Kunci : Motivasi; Kompensasi; Produktivitas Kerja

\begin{abstract}
This study aims to determine the effect of work motivation and work compensation on the work productivity of existing employees. The method used in this study is a quantitative method and data were collected using a questionnaire. The number of population and sample is 67 respondents. The analysis used includes: validity test, reliability test, normality test, multicollinearity test, heteroscedasticity test, simple regression, multiple regression, coefficient analysis, $t$ test and $F$ test. The partial test results obtained work motivation and work compensation have a positive and significant effect on productivity. employee work. While the simultaneous test results of work motivation and work compensation have a positive and significant effect on employee productivity with a value of Fcount 69.437> Ftable and a significance probability of 0.000 with a contribution of $36.9 \%$.
\end{abstract}

Keywords: Motivation; Compensation; Work productivity

\section{PENDAHULUAN}

Semua perusahaan yang bergerak dalam bidang industri, perdagangan maupun jasa akan berusaha untuk mencapai tujuan yang telah ditetapkan untuk mencapai target yang telah ditetapkan pada perusahaan. Pencapaian target yang direncanakan merupakan presatsi yang dibanggakan oleh perusahaan, karena menunjuk-kan kinerja yang baik. Keberhasilan dalam pencapaian target produktivitas, tentunya banyak ditentukan oleh banyak factor. Diantaranya keberadaan sarana dan prasarana serta sumber daya manusia yang berkualitas. Pada era perdagangan bebas saat ini, dalam menghadi persaingan, maka peranan sumber daya manusia perusahaan sangatlah penting dalam mencapai target dan tujuan yang sudah direncanakan. 
Pertiwi Agustina \& Gatot Kusjono: Pengaruh Motivasi Kerja dan Kompensasi Kerja Terhadap Produktivitas Kerja Karyawan

Demikian pula yang dilakukan PT Emka

Putra Pratama juga harus memperhatikan sumber daya manusia perusahaannya. Sebagai perusahaan retail yang memproduksi baju dan telah berkembang pesat dan dikenal dipasaran maupun sosial media, selain berusaha untuk mengembangkan jaringan distribusi dan pelayanan yang memuaskan keseluruh target pasar pada perdagangan di mall seluruh Indonesia dan sosial media. Juga harus menjaga dan tingkat produktivitas produk yang disediakannya sehingga dapat memenuhi kebutuhan pasar. Produktivitas secara umum diartikan sebagai hubungan antara keluaran (barang-barang atau jasa) dengan masukan (tenaga kerja, bahan, uang). Produktifias adalah ukuran efisiensi produktif. Suatu perbandingan antara hasil keluaran dan masukan. Masukan sering dibatasi dengan tenaga kerja, sedangkan keluaran diukur dalam satuan fisik, bentuk, dan nilai Sutrisno, (2011 : 99). Tohardy dalam Edy Sutrisno (2012:100) berpendapat "produktivitas adalah merupakan sikap mental yang selalu mencari perbaikan terhadap apa yang telah ada. Suatu keyakinan bahwa seorang dapat melakukan pekerjaan lebih baik hari ini". Berikut data produktivitas karyawan PT. Emka Putra Pratama Jakarta Utara dari tahun 2017 sampai 2019.

Tabel 1. Data Produksi karyawan

PT. Emka Putra Pratama Tahun 2017-2019

\begin{tabular}{ccccl}
\hline No & Tahun & $\begin{array}{r}\text { Jumlah } \\
\text { Produksi }\end{array}$ & Target & Ket. \\
\hline 1 & 2017 & 7000 Pcs & 9000 Pcs & $\begin{array}{l}\text { Tidak } \\
\text { Tercapai }\end{array}$ \\
\hline 2 & 2018 & 6000 Pcs & 9000 Pcs & $\begin{array}{l}\text { Tidak } \\
\text { Tercapai }\end{array}$ \\
\hline 3 & 2019 & 3000 Pcs & 9000 Pcs & $\begin{array}{l}\text { Tidak } \\
\text { Tercapai }\end{array}$ \\
\hline
\end{tabular}

Sumber : PT. Emka Putra Pratama.

Berdasarkan data di atas menunjukkan bahwa produktivitas kerja karyawan tidak dapat memenuhi target yang sudah direncanakan. Tidak tercapainya target produktivitas tersebut tentunya dipengaruhi berbagai faktor, baik faktor internal maupun faktor eksternal. Faktor utama yang harus diperhatikan oleh perusahaan diantaranya adalah faktor kualitas sumber daya manusia yang ada. Motivasi karyawan tentunya sangat penting sekali diperhatikan perusahaan dalam mecapai target yang diinginkan. Motivasi kerja sangat berperan dalam meningkatkan produktivitas kerja karyawan (Sunarsi, 2018; Faslah, Savitri, 2013; Mulyadi, 2010).

"Motivasi berasal dari kata latin movere yang berarti dorongan, daya penggerak atau kekuatan yang menyebabkan suatu tindakan atau perbuatan. Kata movere, dalam bahasa inggris, sering disepadankan dengan motivation yang berarti pemberian motif, penimbulan motif, atau hal yang menimbulkan dorongan atau keadaan yang menimbulkan dorongan. Secara harfiah motivasi berarti pemberian motif. Seseorang melakukan sesuatu dengan sengaja, tentu ada suatu maksud dan tujuan yang mendorongnya melakukan suatu tindakan. Motif dasar dari seseorang tersebut adalah adanya kebutuhan orang tersebut akan kebanggaan dan kehormatan serta, mungkin limpahan materi" (Suwatno \& Donni Juni Priansa: 2011,171). Sedangkan menurut Kadarisma (2012: 276), "pengertian motivasi dalam kehidupan sehari-hari diartikan sebagai keseluruhan proses pemberian dorongan atau rangsangan kepada karyawan sehingga mereka bersedia bekerja dengan rela tanpa dipaksa".

Selain motivasi, kompensasi yang diberikan oleh perusahaan juga merupakan faktor yang dapat meningkatkan produktivitas karyawan dalam bekerja. (Handaru dan Susita, 2019: Rumahlaiselan dan Wenas, 2018: Fitrianti dan Prasetio, 2018). Menurut Nawawi (2011:314) "Kompensasi adalah penghargaan/ ganjaran padapara pekerja yang telah memberikan kontribusi dalam mewujudkan tujuannya, melalui kegiatan yang disebut bekerja". Menurut Yani tahun 2012 (dalam Widodo, 2016:155). Kompensasi adalah bentuk pembayaran dalam bentuk manfaat dan insentif untuk memotivasi karyawan agar produktivitas kerja semakin meningkat. Menurut Marwansyah (2016:269) Kompensasi adalah penghargaan atau imbalan langsung maupun tidak langsung, finansial maupun non finansial, 
yang adil dan layak kepada karyawan, sebagai balasan atau kontribusi/ jasanya terhadap pencapaian tujuan perusahaan. Menurut Sastrohadiwiryo, (2011: 125) Kompensasi adalah imbalan saja atau balas jasa yang diberikan perusahaan kepada para tenaga kerja, karena para tenaga kerja tersebut telah memberikan sumbangan tenaga dan pikiran mereka demi kemajuan perusahaan guna mencapai tujuan yang ditetapkan. Berikut data kompensasi yang diberikan perusahaan dalam bentuk gaji mulai tahun 2017 sampai 2019.

Tabel 2. Data Gaji karyawan PT. Emka Putra Pratama Tahun 2017-2019

\begin{tabular}{cccccccc}
\hline No & Tahun & UMP & Gaji & Insentif & Total & Selisih & \% \\
\hline 1 & 2017 & 3.100 .000 & 2.950 .000 & 24.000 & 2.974 .000 & 150.000 & $48,38 \%$ \\
\hline 2 & 2018 & 3.355 .750 & 3.050 .000 & 50.000 & 3.100 .000 & 255.750 & $80,06 \%$ \\
\hline 3 & 2019 & 3.648 .035 & 3.150 .000 & 100.000 & 3.250 .000 & 398.035 & $0,112 \%$ \\
\hline
\end{tabular}

Sumber : PT. Emka Putra Pratama Jakarta Utara Tahun 2017-2019

Berdasarkan tabel di atas, tampak bahwa dalam sistem penggajian yang ditetapkan perusahaan belum belum sesuai dengan standarisasi yang ditetapkan oleh pemerintah provinsi DKI Jakarta. Hal ini tentunya akan berdampak dalam kinerja karyawan dalam mencapai target yang diinginkan. Karena, peningkatan produktivitas kerja karyawan selain ditentukan oleh motivasi kerja juga dipengaruhi oleh kompensasi yang diberikan oleh perusahaan (Yuliannisa, Basrind dan Yani, 2018; Claudia dan Suana, 2018).

Penelitian ini bertujuan untuk mengetahui dan menkaji lebih dalam "Pengaruh Motivasi Kerja dan Kompensasi Kerja Terhadap Produktivitas Kerja Karyawan PT. Emka Putra Pertama Jakarta Utara".

\section{Kerangka berfikir}

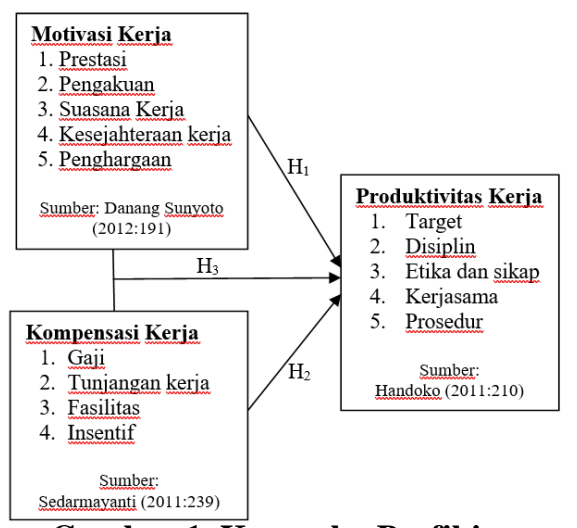

Gambar 1. Kerangka Berfikir

\section{Hipotesis}

Hipotesis yang akan diuji dalam penelitian ini:
$\mathrm{H}_{1}$ : Ada pengaruh motivasi kerja terhadap produktivitas kerja karyawan PT. Emka Putra Pratama,

$\mathrm{H}_{2}$ : Ada pengaruh kompensasi kerja terhadap produktivitas kerja karyawan PT. Emka Putra Pratama,

$\mathrm{H}_{3}$ : Ada pengaruh motivasi kerja dan kompensasi terhadap produktivitas kerja karyawan PT. Emka Putra Pratama.

\section{METODE}

Metode penelitian yang digunakan adalah penelitian survey dengan pendekatan teknik deskriptif kuantitatif, yang artinya memberikan suatu gambaran yang teratur tentang suatu peristiwa akan dibahas dalam menganalisa data kuantitatif data-data yang bersifat angka. Populasi penelitian ini adalah seluruh karyawan PT. Emka Putra Pratama Jakarta Utara dengan jumlah seluruh karyawan adalah 67 karyawan. Analisa data yang digunakan meliputi uji asumsi klasik (normalitas, multikolinieritas, heteroskedastisitas), uji regresi linier berganda, uji determinasi dan uji hipotesis (uji t dan uji F).

\section{HASIL DAN PEMBAHASAN}

\section{Hasil}

Uji Normalitas

Tabel 3. Uji normalitas Kolmogrov-Smirnov One-Sample Kolmogorov-Smirnov Test

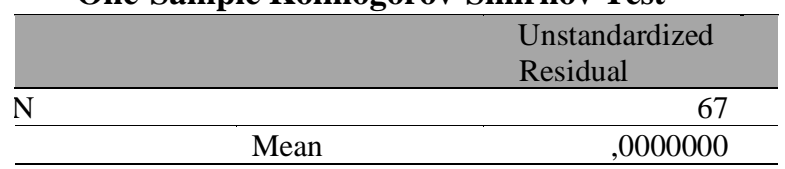


Pertiwi Agustina \& Gatot Kusjono: Pengaruh Motivasi Kerja dan Kompensasi Kerja

Terhadap Produktivitas Kerja Karyawan

\begin{tabular}{llr}
\hline $\begin{array}{l}\text { Normal } \\
\text { Parameters }\end{array}$ & Std. Deviation & 2,08526899 \\
\hline Most Extreme & & Absolute \\
Differences & Positive &, 050 \\
\cline { 2 - 3 } &,- 050 &, 041 \\
\hline Test Statistic &,- 050 \\
\hline Asymp. Sig. (2-tailed) &, 050 \\
\hline a. Test distribution is Normal. & $, 200 \mathrm{c}, \mathrm{d}$ \\
b. Calculated from data. & \\
\multicolumn{2}{l}{ Sumber : Data diolah, 2021 } &
\end{tabular}

Hasil uji normalitas pada sample kolmogorov smirnov di atas diperoleh nilai signifikan sebesar 0,200 >0,05, artinya data terdistribusi normal.

Selain uji kolmogrov-smirnov, uji normalitas juga bisa digunakan dengan melihat grafik p-plots.

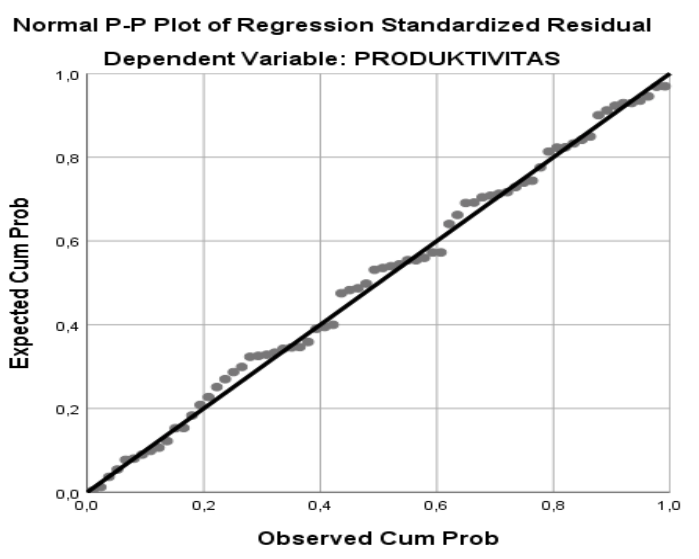

Gambar 1. P - P Plot uji Normalitas Diagram Penyebaran Titik Residual

Melihat tampilan grafik Normal Probability Plot di atas, dapat disimpulkan bhawa pada grafik Normal Probability Plot terlihat titik menyebar disekitar garis diagonal dan penyebarannya mengikuti arah garis diagonal, sehingga dapat disimpulkan bahwa yang digunakan penelitian ini berdistribusi normal.

\section{Uji Heteroskedastisitas}

Pengujian heteroskedastisitas dimaksud-kan untuk menguji apakah dalam sebuah model regresi terjadi ketidaksamaan varians residual menggunakan uji Glesjer dimana hasil uji ini dapat dilihat apakah dalam model regresi terjadi ketidaksamaan varian dari suatu residual pengamatan ke pengematan lain. Hasil uji heteros- kedastisitas seperti yang ditunjukkan pada tabel berikut:

Tabel 4. Hasil Uji Heteroskedastisitas dengan Glejser Coefficients $^{\mathrm{a}}$

\begin{tabular}{lrrrrr}
\hline Model & \multicolumn{2}{c}{$\begin{array}{l}\text { Unstandardized } \\
\text { Coefficients }\end{array}$} & $\begin{array}{c}\text { Standardized } \\
\text { Coefficients }\end{array}$ & t & Sig. \\
\cline { 2 - 7 } & B & $\begin{array}{c}\text { Std. } \\
\text { Error }\end{array}$ & Beta & & \\
\hline Constant) & 48,907 & 4,980 & & 9,822 &, 000 \\
\hline $\begin{array}{l}\text { Motivasi } \\
\text { Kerja }\end{array}$ &, 065 &, 073 &, 111 &, 901 &, 371 \\
\hline $\begin{array}{l}\text { Kompensasi } \\
\text { Kerja }\end{array}$ &, 018 &, 98 &, 023 &, 187 &, 852 \\
\hline
\end{tabular}

a. Dependent Variable: Abs_Res

Sumber : Data diolah, 2021

Berdasarkan hasil pengujian pada tabel diatas, glejser test model pada variabel motivasi kerja dan kompensasi diperoleh nilai probability signifikan (Sig.) lebih besar dari 0,05 . Artinya pada regression model tidak ada gangguan heteroskesdastisitas.

\section{Uji Multikoleniaritas}

Tabel 5. Hasil Uji Multikolonieritas

\begin{tabular}{llrr}
\hline & & \multicolumn{2}{c}{ Collinearity Statistics } \\
\cline { 2 - 4 } Model & Tolerance & VIF \\
\hline 1 & (Constant) & & \\
\cline { 2 - 4 } & Motivasi Kerja &, 975 & 1,026 \\
\cline { 2 - 4 } & Kompensasi Kerja &, 975 & 1,026 \\
\hline
\end{tabular}

Sumber : Data diolah, 2021

Hasil uji multikolonieritas diperoleh nilai VIF lebih kecil dari 10 dan nilai toleransi di atas $10 \%$ atau 0,1 yang berarti dari data tidak terjadi multikolonieritas.

\section{Uji Regresi Linear Berganda}

Tabel 6. Hasil Uji Regresi Berganda

Coefficients $^{\mathrm{a}}$

\begin{tabular}{|c|c|c|c|c|c|}
\hline \multirow[b]{2}{*}{ Model } & \multicolumn{2}{|c|}{$\begin{array}{c}\text { Unstandardized } \\
\text { Coefficients }\end{array}$} & $\begin{array}{c}\text { Standardized } \\
\text { Coefficients }\end{array}$ & \multirow[t]{2}{*}{$\mathrm{t}$} & \multirow[t]{2}{*}{ Sig. } \\
\hline & B & $\begin{array}{l}\text { Std. } \\
\text { Error }\end{array}$ & Beta & & \\
\hline (Constant) & 11.561 & 3.522 & & 3.283 & .002 \\
\hline Motivasi & 1.593 & .351 & 1.590 & 4.544 & .000 \\
\hline Kompensasi & -.862 & .379 & -.795 & -2.271 & .027 \\
\hline
\end{tabular}

a. Dependent Variable: Produktivitas Kerja

Sumber : Data diolah, 2021

Berdasarkan hasil uji pada tabel di atas, dapat disusun persamaan regresi linear berganda: $\mathrm{Y}=11,581+1,593 \mathrm{X}_{1}-0,862 \mathrm{X}_{2}$, Interprestasi dari persamaan regresi tersebut: 
Pertiwi Agustina \& Gatot Kusjono: Pengaruh Motivasi Kerja dan Kompensasi Kerja Terhadap Produktivitas Kerja Karyawan

bahwa Motivasi Kerja berpengaruh terhadap Produktivitas Kerja.

Hasil uji parsial pengaruh kompensasi kerja terhadap produktivitas kerja karyawan diperoleh nilai $\mathrm{t}_{\text {hitung }} 2,271>\mathrm{t}_{\text {tabel }} 1,9977$ dengan nilai probabilitas sig $0,027<0.05$. Artinya terdapat pengaruh positif Kompensasi Kerja $\left(\mathrm{X}_{2}\right)$ Terhadap Produktivitas Kerja Karyawan (Y) pada PT. Emka Putra Pratama, Jakarta Utara. Hasil ini sejalan dengan penelitian Dewi (2014), Hasibuan (2017), Malayu S.P Hasibuan (2014), bahwa Kompensasi Kerja berpengaruh terhadap Produktivitas Kerja.

Hasil uji simultan pengaruh motivasi kerja dan kompensasi kerja diperoleh hasil uji $\mathrm{F}$ hitung $69,437>\mathrm{F}_{\text {tabel }}(3,14)$ dengan probabilitas sig $0,000<0,05$. Artinya terdapat pengaruh signifikan motivasi kerja dan kompensasi kerja terhadap produktivitas kerja karyawan pada PT. Emka Putra Pratama, Jakarta Utara dengan konstribusi sebesar 67,5\%. Hasil ini sejalan dengan penelitian yang dilakukan oleh Mangkunegara (2017), Sedarmayanti (2010), Sutrisno (2017), Hasibuan (2013), bahwa Motivasi Kerja dan kompensasi Kerja berpengaruh terhadap Produktivitas Kerja.

\section{SIMPULAN}

Secara parsial motivasi kerja berpengaruh terhadap produktivitas kerja Karyawan PT. Emka Putra Pratama, Jakarta Utara dengan nilai $t_{\text {hitung }} 4,544>t_{\text {tabel }} 1,9977$ dan nilai probabilitas sig $0,000<0.05$. Demikian juga kompensasi kerja secara parsial juga berpengaruh terhadap Produktivitas Kerja Karyawan PT. Emka Putra Pratama, Jakarta Utara dengan nilai $t_{\text {hitung }} 2,271>t_{\text {tabel }} 1,9977$ dan nilai probabilitas Sig 0,027 .

Secara simultan motivasi kerja dan kompensasi kerja berpengaruh signifikan terhadap Produktivitas Kerja karyawan pada PT. Emka Putra Pratama Jakarta Utara dengan hasil nilai $f_{\text {hitung }}>\mathrm{f}_{\text {tabel }} 69,437>3,14$ dan nilai sig $0.000<0.05$. Adapun konstribusi pengaruh motivasi kerja dan kompensasi kerja sebesar $67,5 \%$.
Perlu adanya penelitian lanjutan yang dapat mengungkapkan faktor-faktor lainnya yang mempengaruhi produktivitas kerja karyawan selain motivasi dan kompensasi kerja.

\section{DAFTAR PUSTAKA}

Agung Ngurah Bagus Dhermawan I Gde Adnyana Sudibya I Wayan Mudiartha Utama Jurnal Manajemen Udayana Strategi Bisnis, dan Kewirausahaan Vol. 6, No. 2 Agustus 2012 Pengaruh Motivasi Lingkungan Kerja, Dan Kompensasi Terhadap Kepuasan Kerja Dan Kineja Di Lingkungan Kantor Dinas Pekerjaan Umum Provinsi Bali

Apfia Ferawati, Jurnal Manajemen Bisnis, URL: Jurnal Ilmu Manajemen VOL. 4 No. 4 (2017) URL

https://jurnalmahasiswa.unesa.ac.id

Denok Sunarsi. 2018. Pengaruh Motivasi dan Disiplin Terhadap Produktivitas Kerja Karyawan PT. Nadi Suwarna Bumi PISSN 2615-6849, Vol 1, No. 1, Februari 2018, Hal (66- 82)

Faslah, Roni, and Meghar Tremtari Savitri. "Pengaruh Motivasi Kerja Dan Disiplin Kerja Terhadap Produktivitas Kerja Pada Karyawan Pt. Kabelindo Murni, Tbk." Jurnal Pendidikan Ekono Faslah, R., \& Savitri, M. T. (2013).

Futures Banjarmasin." Administraus 2.1 (2018): 93-106.

Handaru, Agung Wahyu, and Dewi Susita. 2019. "Pengaruh Kompensasi Dan Lingkungan Kerja Terhadap Produktivitas Kerja Karyawan (Kasus Pt Artolite Indah Mediatama)." JRMSIJurnal Riset Mana-jemen Sains Indonesia 10.2: 386-404.

Handoko,T.Hani.2014.Manajemen Personalia dan Sumber Daya Manusia. Yogyakarta: BDFE-Yogyakarta,2014.

Handoko.2013. Manajemen Edisi 2. Yogyakarta: BPFE-Yogyakarta.. 
Hasibuan.2012. Manajemen Sumber Daya Manusia, Edisi Revisi, Bumi Aksara. Jakarta.

Maharlin, Reninda. 2013. "Pengaruh motivasi kerja terhadap produktivitas kerja karyawan robinson supermarket Samarinda." Jurnal Ilmu Administrasi Bisnis 1.4: 298-314.

Mangkunegara, A.A Anwar Prabu, 2011. "Manajemen Sumber Daya Manusia",

Maria Angelica, Jurnal Ilmiah Manajemen 6 (4), 498-508, 2018 Pengaruh Motivasi Kerja dan Kompensasi Kerja terhadap Produktivitas Kerja Karyawan PT. Sinarmas Rendranusa PekanBaru

Nurzaman, Kadar. 2014. Manajemen Personalia. Bandung: CV pustaka Setia.

Oh, Andi, And Maria Angelica. "Analisis Pengaruh Motivasi Kerja Dan Kompensasi Kerja Terhadap Produktivtas Kerja Karyawan Pt. Sinarmas Rendranusa Pekanbaru." Procuratio: Jurnal Ilmiah Manajemen 6.4 (2018): 498-508.

Resta Yulyanti Universitas Pamulang Jurnal Ilmu Manajemen VOL : 1 No : 2 (2019) URL : http://eprints.unpam.ac.id

Roni Faslah,Meghar Tremtari Savitri, Jurnal Pendidikan Ekonomi dan Bisnis (JPEB) 1(2),40-53,2013 Pengaruh Motivasi Kerja Dan Disiplin Kerja Terhadap Produktivitas Kerja Pada Karyawan PT.Kebelino Murni,Tbk

Rumahlaiselan, Angel, and Rudy S. Wenas. "Pengaruh Pelatihan dan Kompensasi Terhadap Produktivitas Kerja Karyawan pada PT Sumber Alfaria Trijaya, Tbk Cabang Manado." Jurnal EMBA: Jurnal Riset Ekonomi, Manajemen, Bisnis dan Akuntansi 6.4 (2018).

Santoni, Ni Putu Cindyana Claudia, and I. Wayan Suana. "Pengaruh Kompensasi, Motivasi, Disiplin Kerja Terhadap Produktivitas Kerja Karyawan Divisi Sales Di Honda Denpasar Agung." EJurnal Mana-jemen 7.10 (2018): 53795406.
Santoso, Slamet. Statistika Ekonomi Plus Aplikasi SPSS. Ponorogo:UNMUH Ponorogo Press, 2014.

Sedarmayanti. 2011. Manajemen Sumber Daya Manusia, Reformasi Birokrasi

Sedarmayanti. Tata Kerja dan Produktivitas Kerja. Bandung:CV Mandar Maju, 2011.

Septeria Noor Yuliannisa,Gerilyansyah Basrindu, Anhar Yani, Jurnal Administraus 2 (1),93-106,2018 Pengaruh Kompensasi Dan Motivasi Terhadap Produktivitas Kerja PT.Inter Pan Pasifik Futures Banjarmasin

Shannon Cecilia Y, Jurnal EMBA URL: https://ISSN2303-1174 Vol.5 No.5 (2015), Pengaruh Disiplin, Motivasi Semangat Kerja Terhadap Produktivitas Kerja Pegawai Dinas Pendapatan Daerah Kota Manado.

Sugiyono, 2010. "Statistik Penelitian", Penerbit Pustaka Setia, Bandung.

Sunarsi, Denok. Pengaruh Motivasi dan Disiplin Terhadap Produktivitas Kerja karyawan Pada PT. Nadi Suwarna Bumi. Http://openjournal .unpam.ac.id/index.php/ar ticle/view/1247.

Suseno, dan Edy. 2010. Manajemen Sumber Daya Manusia. Edisi Pertama. Cetakan

Sutrisno, (2014), Manajemen Sumber Daya Manuasia. Kencana Prenada Media Group.

Zuchri Abdussamad, Jurnal Manajemen Untar 18 (3), 112536, 2014 Pengaruh Kompensasi Terhadap Produktivitas Kerja Karyawan PT. Auransi Jiwasraya Gorontalo 